\title{
The Management Accounting Practices in Albania in the Context of Globalization
}

Submitted: May $25^{\text {th }}, 2010$

Accepted: September $22^{\text {nd }}, 2010$

\section{Summary}

The main aim of the paper is to provide relevant findings on the status of management accounting in Albanian Accounting Practices, based on the direct survey with selected companies and individuals (experts on the field). In our analysis we have used as a benchmark the IFAC statement on Management Accounting Concepts and its description of the evolution of management accounting. To achieve our objectives we prepared and provided to a large group of professional accountants (that mainly are dealing with bookkeeping and financial statement preparations) a structured questionnaire, containing several questions on the status of the practices applied in Albania on management accounting. This survey was carried out during the first half of 2009.

Findings of this paper are based on the answers given by 300 respondents. These answers point out that management accounting practices in Albania tend not to be complex and sophisticated. Budgeting, product profitability and financial performance measurement remain the central pillars, while other, most contemporary, management accounting techniques are sporadically used. There is also little evidence of management accounting concerned directly with "value creation".

\section{Introduction}

Many papers and other publications focused on the development of accounting were written during $80 \mathrm{~s}$, strongly criticize the management accounting practices of that time.

${ }^{*}$ Ph.D., Faculty of Economy, Tirana University, Albania.

${ }^{* *}$ Ph.D., Executive Director of Institute of Certified Accountants of Albania IEKA.

${ }^{* * *}$ Ph.D., Faculty of Economy, Tirana University, Albania. 
"Virtually all of the [management accounting] practices employed by firms today and explicated in leading cost accounting textbooks had been developed by 1925 (...) there has been little innovation in the design and implementation of cost accounting and management accounting control systems" (Kaplan, 1984).

Since then, and perhaps in response to these criticisms, a number of innovative management accounting techniques have been developed across a world.

The most notable contributions are activity based techniques, strategic management accounting and the balanced scorecard. These techniques have been designed to support modern technologies and management processes, such as total quality management and just-in-time production systems, and the search for a competitive advantage to meet the challenge of global competition.

It has been argued that these "new" techniques have affected the whole process of management accounting (planning, controlling, decision-making, and communication) and have shifted its focus from a "simple" or "naïve" role of cost determination and financial control, to a "sophisticated" role of creating value through improved deployment of resources.

The sophistication refers to the capability of a management accounting system to provide a broad spectrum of information relevant for planning, controlling and decision-making, generally aiming at creating or enhancing value.

The next section gives the research framework and articulates in more details the research questions, followed by details of the empirical design. The survey findings are then summarised by a discussion of their implications. The last section sets out the conclusions.

\section{The research framework and research questions}

\subsection{Evolution of management accounting}

In 1998 the International Federation of Accountants (IFAC) issued a statement describing the development of management accounting through four sequential phases:

\section{- Phase 1 - Cost determination and financial control}

IFAC describes management accounting before 1950 as a technical activity necessary to pursue organisational objectives. It was oriented to the determination of product cost. Production technology was relatively simple, with products going through a series of distinct processes. Labour and material costs were easily identifiable and the manufacturing processes were mainly governed by manual operations. Hence, direct labour provided a natural basis for assigning overheads to individual products.

The focus on product costs was supplemented by budgets and the financial control of production processes. Management was concerned primarily with internal matters, especially production capacity. The use of budgeting and cost accounting technologies was prevalent in this period. However, the dissemination of cost information tended to be slight, and its use for management decision-making poorly exploited (Ashton et al., 1995). 


\section{- Phase 2 - Information for management planning and control}

In the $50 \mathrm{~s}$ and $60 \mathrm{~s}$ of 20 -th century the focus of management accounting shifted to the provision of information for planning and control purposes. In this phase, the management accounting is seen by IFAC as a management activity, but in a staffing role. It involved staff (management) support to line management through the use of such technologies as decision analysis and responsibility accounting.

Management accounting, as part of a management control system, tended to be reactive, identifying problems and actions only when deviations from the business plan took place (Ashton et al., 1995).

\section{- Phase 3 - Reduction of resource waste in business processes}

The world recession in the 1970s following the oil price shock increased global competition in the early 1980s, that was accompanied and underpinned by rapid technological development which affected many aspects of the industrial sector. The use of computer-controlled processes improved quality and, in many cases, reduced costs. Also developments in computers, especially the emergence of personal computers, markedly changed the nature and amount of data which could be accessed by managers.

The challenge of meeting global competition was met by introducing new management and production techniques, and at the same time controlling costs, often through reduction of waste in resources used in business processes (IFAC, 1998).

Management accountants role, as the primary providers of this kind of information, was to ensure that, through the use of process analysis and cost management technologies, appropriate information could be available to support managers and employees at all levels.

\section{- Phase 4 - Creation of value through effective resources use}

In the 1990s world-wide industry continued to face considerable uncertainty and unprecedented advances in manufacturing and information-processing technologies (Ashton et al., 1995).

The focus of management accountants shifted to the generation or creation of value through the effective use of resources. This was to be achieved through the use of technologies which examine the drivers of customer value, shareholder value, and organisational innovation (IFAC,1998).

A critical difference between Phase 2, Phase 3, and Phase 4 is the change in focus away from information provision and towards resource management, in the form of waste reduction (Phase 3) and value creation (Phase 4).

Management accounting is an integral part of the management process, as real time information becomes available to management directly and as the distinction between staff and line management becomes blurred. The use of resources (including information) to create value is an integral part of the management process in contemporary organisations. 


\subsection{Performance management systems}

Nowadays, when we live in an era when markets tend to be more and more global and more transparent, there is no doubt that Albanian business entities should improve their management practices accordingly and become more aware on such developments.

Companies today require leaders who develop policies and strategies that really address the needs of the customer and utilise the full potential of their employees. Performance against policies and strategies needs to be monitored using a performance measurement system that addresses all the financial and non-financial measures that are critical to an organisation's success.

What we may learn from Mann et al (1999b) is that industry needs to be more progressive and more willing to learn and apply new methods.

The purpose of our study can be seen as an extension of what was mentioned above, as far as it seeks to identify the level of sophistication of management accounting practices, which are an important part of companies' management control systems.

\subsection{The research question}

To properly design such a paper we carried out several readings on the papers and researches in the field of management accounting practices. So, Chenhall and Langfield-Smith (1997), Guilding, Lamminmaki, and Drury (1998), Luther and Longden (2001) were amongst the authors, whose studies report on the use of various management accounting techniques in different countries.

Our study builds on, and is informed by, the tradition and accumulated findings of such research. However, our work is simply an empiric test of the IFAC's model of management accounting evolution, which will help to address the following research questions: "How sophisticated are management accounting systems in Albanian reality, and what does this tell us about its phase of evolution?"

\section{Research design and data collection}

A postal (e-mail) questionnaire was used to collect empirical data, during the first half of 2009. This way of communication facilitated to access a large number of respondents and provided us with sufficient data for statistical analysis. In addition to, face-to-face interviews were carried out to refine the questionnaire ex ante and to check the reliability of the survey results ex post and seek further explanations on some of the responses given.

We use a number of criteria in selecting certified accountants and include them in the sample: In order to select proper professionals we used the following criteria to be met by them:

- to be member of a professional body of accountants,

- to provide their services for those companies that employee at lest 35 people,

- to serve to those domestic companies that are active in the market. 
The relevant data collected at the Institute of Certified Accountants of Albania, was used as a population for selecting sampling size. The questionnaire was sent to 150 people, members of this institute that met the abovementioned criteria.

Respondents were asked to indicate the frequency of use of 38 management accounting practices (MAPs) using a five point Likert-type scale (1 indicating "never" and 5 indicating "very often"). They were also asked to rate the importance of each technique/practice using either "not important", "moderately important" or "important".

The 38 MAPs were classified into five groups: costing system, budgeting, performance evaluation, information for decision making and strategic analysis. In addition, separate questions were asked concerning the communication of management accounting information.

\section{Survey findings}

\subsection{Costing systems}

Until the end of 90s, although in Albania could be spoken very well on a prudent system of cost accounting (calculation), this is related with the existing or traditional system of cost accounting, where no reference or mention is made to the global achievements of 80 s that relate to the enhancements made on such systems.

The other period between $90 \mathrm{~s}$ and the beginning of 2000 we faced almost a destructive of any of the prior best practices in this field. Such a destructive behaviour is evident in all present accounting practice, regardless of the best efforts made by the professionals to rebuild what was destroyed within a very short time in that period.

Focus of our study were not only practices related with traditional systems of cost accounting, but also new approaches used in cost accounting, mainly those focused on the decision making function. We were able to investigate, the recognition, use and assessment of activity based costing (ABC). Also, target costing and the "costing of quality" were introduced as tools for confronting increased competition.

To find out about the extent to which practitioners applied their costing system to provide more accurate cost information for decision making purposes, respondents were asked to indicate how often and how important are for them seven techniques related to costing systems. The responses are summarised in Table 1.

It can be seen from the answer that $21 \%$ of the companies either "often" or "very often" distinguish between variable/incremental costs and fixed/non-incremental costs for decision making purposes. The importance of this separation was acknowledged by 83 of respondents rating it as either "moderately important" or "important". By contrast only a small number indicated high usage of the three techniques (plant-wide, multiple-rate or $\mathrm{ABC}$ ) for allocation of overhead to cost objects; overhead allocation does not appear to be done very frequently. The combination of these two findings suggests that variable costing is much more common than various forms of absorption costing. While absorption (including $\mathrm{ABC}$ ) costing has a relatively low usage rating, it nevertheless 
Table 1. Seven techniques of costing system

\begin{tabular}{|c|c|c|c|c|c|c|c|c|}
\hline & & How & fften & Ised & & Hou & impo & \\
\hline & S1 & S2 & S3 & S4 & S5 & NI & MI & I \\
\hline $\begin{array}{l}\text { A separation is made between variable/incremental } \\
\text { costs and fixed/non incremental costs }\end{array}$ & 20 & 28 & 37 & 12 & 12 & 28 & 49 & 35 \\
\hline Using a plant-wide overhead rate & 50 & 21 & 18 & 23 & 9 & 27 & 56 & 17 \\
\hline Departmental or multiple plant-wide overhead rates & 54 & 45 & 10 & 3 & 0 & 49 & 35 & 16 \\
\hline Activity-based costing (ABC) & 73 & 30 & 9 & 0 & 0 & 66 & 34 & 12 \\
\hline Target costs & 99 & 9 & 4 & 0 & 0 & 72 & 37 & 5 \\
\hline
\end{tabular}

Source: own study.

seems to have considerable importance; 73,51 and 46 of respondents rated the three forms either "moderately important" or "important".

Respondents are aware of the importance of overhead allocation techniques but many believe that it is not worth implementing them frequently.

The costing of quality is seen to be extremely important but not very frequently calculated. Finally, mathematical modelling of cost relationships and behaviour is neither seen to be important nor often used.

The same conclusions as per the allocation techniques used for industrial costs of production we will say for the cost accounting (calculating) approaches and on the standard cost systems. JIT (Just in Time) production system is percept as important but not applicable.

Lastly, as far as the level of knowledge is concerned, we could say that high level of knowledge exist on allocation of costs, while these knowledge are considerable for other five practices.

\subsection{Budgeting}

The literature of management accounting emphasises that budgeting is an essential technique for planning and controlling the activities of an organisation (Drury et al., 1993). The implementation of $\mathrm{ABC}$ was followed by the introduction of activity based budgeting $(\mathrm{ABB})$. In the questionnaire we asked respondents to rate the usage and the importance of budgeting for planning, budgeting for controlling costs, activity-based budgeting, budgeting with 'what if' analysis, flexible budgeting, zero based budgeting and budgeting for long-term (strategic) planning. In Table 2 we have summarises the responses.

The survey shows that budgeting is either "often" or "very often" used for planning and controlling costs by an overwhelming 38\% and 20\% respectively. Taken together, budgeting for planning and control was considered either "important" or "moderately important" by more than $83 \%$ of respondents. It can be concluded that almost all companies use budgeting for planning and control. Many companies (20\%) use flexible budgeting but $62 \%$ clearly do not flex their budgets at all! "What if" analysis is clearly 
Table 2. Budgeting technics

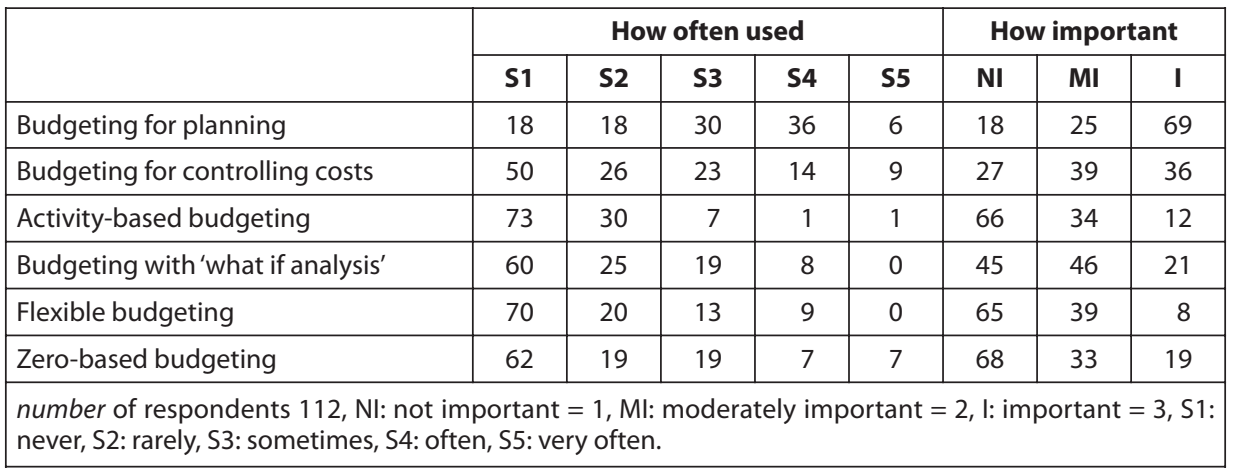

Source: own study.

very important but, as expected, is only applied from time to time. ABB was considered either "moderately important" or "important" by the majority of respondents $(41 \%)$. However, only 2 of respondents were using it "often" or "very often". When ABC and $\mathrm{ABB}$ were cross-tabulated we found that all companies which reported high level of usage for $\mathrm{ABC}$ did the same for $\mathrm{ABB}$. It may be that companies start implementing $\mathrm{ABC}$ and then them use the activities analysis performed during $\mathrm{ABC}$ implementation to prepare their budgets. One would not expect zero-based budgeting to be applied very frequently but it was perhaps surprising to see that it is also seen to be largely unimportant $(60 \%$ of respondents).

\subsection{Performance evaluation}

The choice of measures to guide and evaluate the performance of business units is one of the most critical challenges facing organisations (Ittner and Larcker, 1998).

Management accounting should report all relevant information related to the evaluation of business units' performance. Systems which focus solely on financial measures such as profits, return on investment, standard costs and variance analysis have been widely criticised (e.g. Ittner et al., 1997; Kaplan and Norton, 1996; Shields, 1997). The criticisms arise because these measures are distorted by external reporting conventions, they promote short-terms and accounting manipulation, and do not take into consideration the cost of capital or non-financial "leading" measures such customer satisfaction, labour efficiency or innovation.

To incorporate the cost of capital into financial measures a variety of "economic value" measures have been introduced (Ittner and Larcker, 1998). Kaplan and Norton (1992; 1993 and 1996) introduced the Balanced Scorecard (BSC) as a way of integrating financial and non-financial performance measures. Benchmarking concept was introduced and made popular as an organisational improvement tool by the Xerox. Benchmarking is based on identifying a "best practice" either internally or externally and then studying how this can be used to improve current and future performance. 
We asked respondents to rate the usage and importance of several groups of measures:

1.Financial measures;

2.EVA;

3. Benchmarks;

4. Non-financial measures related respectively to customers, to operations and innovation, and to employees.

In Table 3 we can show the results. As expected, the majority of respondents (84\%) rated financial measures as an "important" and about the same percentage reported frequent usage of these measures. Non-financial measures related to customers and to operations, and innovation are clearly very influential with $78 \%$ and $51 \%$ respectively scoring them as at least "moderately important". However, a significant minority of companies ( $56 \%$ for both categories of measures) produce such measures either "never" or "rarely". The non-provision of employee related measures is even more marked, with $53 \%$ of respondents answering "never". The results show also that neither EVA nor benchmarking have yet gained popularity.

Table 3. Performance measures

\begin{tabular}{|l|c|c|c|c|c|c|c|c|}
\hline & \multicolumn{4}{|c|}{ How often used } & \multicolumn{3}{c|}{ How important } \\
\cline { 2 - 9 } & S1 & S2 & S3 & S4 & S5 & NI & MI & I \\
\hline Financial measure(s) & 10 & 24 & 22 & 32 & 24 & 7 & 36 & 59 \\
\hline Non-financial measure(s) related to customers & 30 & 16 & 28 & 20 & 18 & 14 & 43 & 45 \\
\hline $\begin{array}{l}\text { Non-financial measure(s) related to operations } \\
\text { and innovation }\end{array}$ & 54 & 25 & 19 & 14 & 0 & 37 & 48 & 27 \\
\hline Non-financial measure(s) related to employees & 60 & 28 & 14 & 10 & 0 & 36 & 53 & 21 \\
\hline Economic value added & 88 & 10 & 13 & 0 & 0 & 74 & 29 & 9 \\
\hline Benchmarks & 52 & 18 & 19 & 14 & 9 & 43 & 48 & 31 \\
\hline
\end{tabular}

number of respondents 112, NI: not important = 1, MI: moderately important = 2, I: important = 3, S1: never, S2: rarely, S3: sometimes, S4: often, S5: very often.

Source: own study.

\subsection{Information for decision-making}

One of the objectives of management accounting is to provide relevant information for internal decision making. For regular or short-term decisions management accountants can use cost-volume-profit analysis, product profitability analysis and stock control models. For capital investment decisions management accountants can produce accounting rates of return and payback periods as well as more complex signals based on discounted cash flow. Also information on non-financial factors, such as quality of output, flexibility of processes and lead-times could affect capital investment projects.

Summaries of the responses to questions about decision-making practice of management accounting are shown in Table 4. It can be seen that product profitability analysis and customer profitability analysis are "often" or "very often" calculated in the majority of companies $-24 \%$ and $42 \%$ respectively. Respondents also rated these analyses 
Table 4. Decision making practices

\begin{tabular}{|l|c|c|c|c|c|c|c|c|}
\hline \multirow{2}{*}{} & \multicolumn{3}{|c|}{ How often used } & \multicolumn{3}{c|}{ How important } \\
\cline { 2 - 9 } & S1 & S2 & S3 & S4 & S5 & NI & MI & I \\
\hline $\begin{array}{l}\text { Cost-volume-profit analysis (break-even analysis) } \\
\text { for major products }\end{array}$ & 19 & 28 & 38 & 12 & 12 & 28 & 49 & 35 \\
\hline Product profitability analysis & 50 & 16 & 18 & 23 & 5 & 16 & 24 & 72 \\
\hline Customer profitability analysis & 30 & 16 & 18 & 20 & 28 & 14 & 43 & 55 \\
\hline $\begin{array}{l}\text { Evaluation of major capital investments based on } \\
\text { discounted cash flow method(s) }\end{array}$ & 69 & 30 & 10 & 3 & 0 & 36 & 45 & 31 \\
\hline $\begin{array}{l}\text { Evaluation of major capital investments based on } \\
\text { payback period and/or accounting rate of return }\end{array}$ & 50 & 10 & 24 & 28 & 0 & 23 & 44 & 45 \\
\hline $\begin{array}{l}\text { Performing sensitivity'what if' analysis when } \\
\text { evaluating major capital investment projects }\end{array}$ & 60 & 25 & 19 & 8 & 0 & 45 & 46 & 21 \\
\hline $\begin{array}{l}\text { Calculation and use of cost of capital in } \\
\text { discounting cash flow for major capital investment } \\
\text { evaluation }\end{array}$ & 69 & 30 & 10 & 3 & 0 & 36 & 57 & 19 \\
\hline
\end{tabular}

number of respondents $112, \mathrm{NI}$ : not important $=1$, MI: moderately important $=2$, I: important $=3, \mathrm{~S} 1$ : never, S2: rarely, S3: sometimes, S4: often, S5: very often.

Source: own calculation.

as "important" $-85 \%$ and $72 \%$ respectively. CVP analyses are seen to be "important" or "moderately important" by $75 \%$ of respondents and are also surprisingly frequently produced $-23 \%$ indicating that such analyses are used at least "often". Stock control models are largely "moderately important" and "sometimes used".

Regarding capital investment decisions, $50 \%$ of respondents used traditional accounting measures such as accounting rate of return and payback period to evaluate major capital projects, while the equivalent figure for discounted cash flow models such as internal rate of return and net present value is only $10 \%$. This apparent scepticism of 'advanced' investment appraisal is confirmed by the figure of $32 \%$ answering that calculating the cost of capital was "not important"! Finally 'what if' analysis is the most popular technique in evaluating the risk of projects though only $43 \%$ of respondents used it "often" or "very often".

\subsection{Strategic analysis}

Traditional management accounting systems have been criticised because they focus on reporting information related to internal processes with little attention being given to the external environment and the effect of competitors' decisions and cost structures on current and future processes of the business. The externally oriented approach has become known as "strategic management accounting", a term that first appeared as the title of an article by Simmonds in 1981. However, there is no agreed conceptual framework for what constitutes strategic management accounting. These are: a concern with customers and the external environment; a focus on competitors; and a long-term, forward-looking orientation. 
Table 5. Strategic analyses techniques

\begin{tabular}{|l|r|r|r|r|r|r|r|r|}
\hline \multirow{2}{*}{} & \multicolumn{4}{|c|}{ How often used } & \multicolumn{3}{c|}{ How important } \\
\cline { 2 - 11 } & S1 & S2 & S3 & S4 & S5 & NI & MI & I \\
\hline Long-range forecasting & 46 & 24 & 18 & 12 & 12 & 24 & 41 & 47 \\
\hline Shareholder value & 50 & 16 & 18 & 13 & 9 & 65 & 28 & 19 \\
\hline Industry analysis & 54 & 15 & 24 & 9 & 0 & 33 & 40 & 39 \\
\hline Analysis of competitive position & 73 & 30 & 9 & 0 & 0 & 54 & 28 & 29 \\
\hline Value chain analysis & 99 & 9 & 4 & 0 & 0 & 63 & 48 & 1 \\
\hline Product life cycle analysis & 90 & 12 & 5 & 5 & 0 & 54 & 37 & 21 \\
\hline $\begin{array}{l}\text { Analysis of competitors' strengths and } \\
\text { weaknesses. }\end{array}$ & 43 & 25 & 20 & 13 & 12 & 17 & 50 & 44 \\
\hline
\end{tabular}

number of respondents $112, \mathrm{NI}$ : not important $=1$, MI: moderately important $=2$, I: important $=3$, S1: never, S2: rarely, S3: sometimes, S4: often, S5: very often.

Source: own study.

Eight strategic practices were given to respondents who were asked to indicate how often they use them as well as their importance. See Table 5 for the results.

It can be seen that only long-range forecasting was "often" or "very often" done by only $(21 \%)$ of the companies. This was followed in frequency by the analysis of shareholder value $(21 \%)$ and the analysis of competitors' strengths and weaknesses $(20 \%)$. It may be concluded that companies are, at present, more interested in conventional long-range (forward-looking) planning and lateral competitive analyses than in contextual stakeholder, industry, life-cycle or value chain analyses. The high scoring of importance, relative to frequency of use, of analyses of competitive position (and competitors' strengths and weaknesses) and of value chains suggests that the application of these practices may become more widespread and frequent.

\section{Conclusions}

Our findings are based on the analysis of 112 questionnaires completed by accountants. Some notable findings are identified below.

The separation of costs into variable and fixed was acknowledged to be at least "moderately important" by $74 \%$ of respondents and in almost half the companies the distinction is "sometimes" or "often" applied. This contrasted with lower levels of importance and usage of $\mathrm{ABC}$ and other full costing techniques.

Budgeting for planning and control is either "important" or "moderately important" for more than $83 \%$ of companies. It was interesting that a high proportion does not flex or amend their budgets for changes in volumes or other factors, but work only with fixed budgets. "What if" analyses are, however, fairly frequently applied.

Activity based budgeting, in common with activity based costing, and has higher ratings of importance than actual usage. There seems to be very little resonance in firms 
with the concerns expressed by Hope and Fraser, and others, in the 'Beyond budgeting' literature.

Over three quarters of companies consider financial measures of performance to be fully "important". Non-financial performance measures are also highly important, especially in connection with customer satisfaction. However, despite this importance, some $43 \%$ of companies reported that they "never" or "rarely" actually used non-financial measures of performance in connection with customers, operations, innovation or employees. We get here an impression that the balanced scorecard is more talked about than applied, and that performance measurement is still very much dominated by financial figures.

CVP analysis is considered to be at least "moderately important" by a high proportion of respondents - a finding which ties in with the prominence, mentioned above, that is given to splitting costs into fixed and variable. As expected, the majority of companies apply product profitability analysis not frequently;

We found a scepticism about DCF investment appraisal as compared with earnings-based or payback methods. This finding was corroborated by the fact that $42 \%$ of respondents indicated that calculation of cost of capital was not important in their companies. Non-financial factors relating to capital projects are perceived to be either "important" or "moderately important" by $63 \%$ of respondents, but only $31 \%$ of companies "sometimes" or "often" report and document such factors.

Strategic analysis techniques "come across" as "moderately important", but mostly not very frequently applied. The high scoring of importance, relative to frequency of use, of analyses of competitive position (and competitors' strengths and weaknesses) and of value chains suggests that the application of these practices may become more widespread.

We derived a composite statistic of MAP "emphasis" by multiplying scores of importance and usage. As an absolute measure emphasis is not especially meaningful.

The following practices are shown to have pre-eminent emphasis: Budgeting for planning and for controlling costs, Product profitability analysis, and Performance evaluation based on financial measures. We conclude that traditional management accounting is very much alive and well.

In Table 6 we have tentatively suggested various MAPs which will become increasingly used and those that will gradually be phased out. We have done this by identifying practices where the importance is significantly higher (or lower) than the present level of usage. The data suggests that, of the more sophisticated techniques, increased use may be expected of the following:

- information concerning the cost of quality,

- non-financial measures relating to employees,

- analysis of competitors' strengths and weaknesses.

From this we identify those practices which are placed significantly differently. On the assumption that, over time, the ranking of usage will, in many cases, move towards the ranking of importance, our interpretation is that practices ranked markedly higher in terms of 'importance' than 'usage' are likely to become more widespread and vice versa. 
Table 6. MAPs in the nearest future in Albania

\begin{tabular}{|l|l|}
\hline MAPs that will be phased out & MAPs that will be increasingly adopted \\
\hline Plant-wide overhead rates & Cost-volume-profit analysis for major products \\
\hline Separation between fixed and variable Costs & Investment appraisal using DCF \\
\hline Departmental overhead rates & Info concerning cost of quality \\
\hline & Non-financial measures related to employees \\
\hline & Analysis of competitors' strengthsand weaknesses \\
\hline
\end{tabular}

Source: own study.

\section{References}

Chapman S.C., Controlling strategy: Management, Accounting, and Performance Measurements, Oxford University Press, Great Britain 2005.

Cross K.F., Lynch R.L., The SMART way to define and sustain success, National Productivity Review, 1989.

Fernandes K.J., Raja V., Whalley A., Lessons from implementing the balanced scorecard in small and medium size manufacturing organization, Technovation, 2006.

Gomes C.F., Yasin M.M., Lisboa J.V., Performance measurement practices in manufacturing firms: an empirical investigation, "Journal of Manufacturing Technology Management", 2005.

Goold M., Campbell A., Strategies and styles: The Role of the Center in Managing Diversified Corporations, Blackwell, Oxford 1987.

Harrison A. von Hoek R., Logistics Management and Strategy, Pearson Education Limited, Edinburgh 2005.

Johnson H.T., Relevance Regained. From top down control to bottom up empowerment, The Free Press, New York 1992.

Kaplan R.S., Norton D.P., Translating Strategy into Action. The Balanced Scorecard, Harvard Business School Press, Boston, 1996.

Kaplan R.S., Norton D.P., The Strategy-Focused Organization, Harvard Business School Press, Boston 2001.

Keegan D.P., Eiler R.G., Jones C.R., Are your performance measures obsolete?, "Management Accounting”, 1989.

Merchant K.A., Stede W.A., Management Control Systems: Performance Measurement, Evaluation and Incentives, Pearson Education Limited, England 2007.

Niven P.R., Balanced Scorecard: Diagnostics Maintaining, Maximum Performance, John Wiley and Sons Inc., New Jersey 2005.

Olve N.G., Petri C.J., Roy J., Roy S., Twelve years later: Understanding and realizing the value of balanced scorecards, Ivey Management Services, 2004.

Simons R., Performance Measurement and Control Systems for Implementing Strategy, Prentice Hall, New Jersey 2000. 


\section{Praktyka rachunkowości zarządczej w Albanii w kontekście globalizacji}

\section{Streszczenie}

Głównym celem artykułu jest wykazanie stosowanych zasad rachunkowości zarzadczej w praktyce rachunkowości w Albanii. Rozważanie przedstawione zostały na podstawie rezultatów wywiadu bezpośredniego przeprowadzonego w I pot. 2009 r. w wybranych przedsiębiorstwach oraz wśród praktyków, ekspertów zajmujących się opisywanym zagadnieniem. Analizie poddano 300 uzyskanych odpowiedzi. Na tej podstawie wykazano ewolucję zasad rachunkowości w Albanii i ich porównywalność ze standardami rachunkowości określonymi przez IFAC. Wykazano również stopień powiqzania rachunkowości zarzqdczej z koncepcja tworzenia wartości przedsiębiorstw $w$ otoczeniu globalnym. 